\title{
The use of intraaortic balloon pumping as an adjunct to reperfusion therapy in acute myocardial infarction
}

\author{
E. Magnus Ohman, MB, Robert M. Califf, MD, Barry S. George, MD, \\ Peter J. Quigley, MD, Dean J. Kereiakes, MD, Lynn Harrelson-Woodlief, MS, \\ Richard J. Candela, MD, Cyndi Flanagan, BSN, Richard S. Stack, MD, \\ Eric J. Topol, MD, and the Thrombolysis and Angioplasty in Myocardial Infarction \\ (TAMI) study group. Durham, NC, Ann Arbor, Mich., \\ and Columbus and Cincinnati, Ohio
}

Although the intraaortic balloon pump (IABP) has been useful in supporting patients with specific mechanical complications of infarction that could be approached with corrective surgery, ${ }^{1}$ it has not been found to be useful as routine therapy in conservatively treated acute myocardial infarction. The concepts of using the IABP to reduce myocardial oxygen demand $^{2}$ or to support the failing left ventricle ${ }^{3}$ have been theoretically attractive. However, in uncomplicated myocardial infarction in the absence of reperfusion, the IABP has not been shown to reduce infarct size. ${ }^{4}$ Furthermore, although short-term survival of patients in cardiogenic shock without correctable mechanical complications has been enhanced, the long-term outcome has remained unchanged by use of the IABP before the advent of reperfusion therapy. ${ }^{5}$

Coronary artery reperfusion with thrombolytic therapy, ${ }^{6,7}$ percutaneous coronary angioplasty, ${ }^{8}$ or both have offered a new opportunity to enhance outcome with the IABP by several possible mechanisms. Although reperfusion reduces infarct size and eventually improves left ventricular function, ${ }^{9}$ the function of ischemic myocardium does not immediately

From the Division of Cardiology, Department of Medicine, Duke University Medical Center; University of Michigan, Ann Arbor; Riverside Methodist Hospital, Columbus; and Christ Hospital, Cincinnati.

Supported by research grants HS-04873 and HS-05635 from the National Center for Health Services, research grants from Genentech, Inc., San Francisco, Calif. and Abbott Laboratories, Chicago, Ill., and by a scholarship from the Andrew W. Mellon Foundation, New York, N.Y. (Dr. Ohman).

Received for publication July 5, 1990; accepted Aug. 20, 1990.

Reprint requesta: E. Magnus Ohman, MB, Duke University Medical Center, Box 3151, Durham, NC 27710.

$4 / 1 / 26486$ improve with reperfusion. ${ }^{10}$ Therefore supporting myocardial function with the afterload-reducing properties of the IABP may be beneficial while awaiting functional recovery. Furthermore, coronary flow is often impaired in the early phase of reperfusion. ${ }^{11}$ Increasing diastolic coronary pressure and flow may enhance the effects of chemical and mechanical means of reperfusion. ${ }^{12}$ Against these potential benefits must be weighed the risks, especially bleeding at the site of femoral artery puncture ${ }^{13}$ and thrombotic complications resulting from obstruction of flow to the legs. ${ }^{14}$

The goal of the current study was to review the experience with the use of the IABP in a large group of patients treated with thrombolytic therapy. In this process we evaluated the risks of the IABP and developed hypotheses concerning the possible benefits of this procedure in specific subsets of patients in the setting of acute myocardial infarction.

\section{METHODS}

Patient population. The study population included 810 consecutive patients who participated in four clinical trials evaluating different therapeutic strategies after administration of thrombolytic therapy. Results of these clinical trials have been reported in detail in previous publications. ${ }^{15-18}$ Common to all protocols was the administration of thrombolytic therapy within 6 hours of the onset of symptoms. All patients met the following criteria: ECG evidence of at least $0.1 \mathrm{mV}$ of ST segment elevation in two or more contiguous leads, absence of previous $\mathbf{Q}$ wave infarction in the distribution of acute ischemic region, and symptoms of ischemia lasting longer than 30 minutes and unresponsive to sublingual nitroglycerin therapy. Criteria for exclusion included a history 
of significant risk of bleeding, previous major surgery, uncontrolled hypertension, cardiogenic shock, prolonged cardiopulmonary resuscitation, or potential pregnancy.

All patients underwent acute cardiac catheterization with a goal of visualization of the infarct-related artery within 90 minutes of administration of thrombolytic therapy. In the Thrombolysis and Angioplasty in Myocardial Infarction (TAMI) I trial, ${ }^{15}$ patients with patent coronary arteries and suitable anatomy for angioplasty were randomly assigned to undergo immediate angioplasty or were considered for deferred angioplasty at the time of hospital discharge. In the TAMI II, ${ }^{16}$ TAMI III, $^{17}$ and urokinase $^{18}$ trials only patients with occluded infarct-related arteries underwent immediate angioplasty. In all of the patients an effort was made to defer angioplasty until the time of hospital discharge.

The first 178 patients in the TAMI I trial received $150 \mathrm{mg}$ of intravenous tissue plasminogen activator (t-PA) over 6 to 8 hours with $60 \mathrm{mg}$ over the first hour, $20 \mathrm{mg}$ in the second and third hours, and $10 \mathrm{mg} / \mathrm{hr}$ for the last 5 hours. The remaining 208 patients were treated with $1 \mathrm{mg} / \mathrm{kg}$ in the first hour with a maximum dose of $90 \mathrm{mg}$ followed by the remainder of the $150 \mathrm{mg}$ dose over a 5 -hour infusion period. The 146 patients in the TAMI II study received escalating doses of t-PA and urokinase. The first 34 patients received $25 \mathrm{mg}$ of $\mathrm{t}-\mathrm{PA}$ and 0.5 to 1 million units of urokinase. In the remaining 112 patients, $1 \mathrm{mg} / \mathrm{kg}$ t-PA was given in combination with 0.5 to 2.0 million units of urokinase. In the TAMI III study all 175 patients were treated with $1.5 \mathrm{mg} / \mathrm{kg}$ of $\mathrm{t}$-PA over 3 hours. In the urokinase study 102 patients were treated with 3 million units of urokinase given over 45 to 60 minutes.

After acute angiography all patients were admitted to cardiac care unit where medical therapy was used, including intravenous lidocaine for 24 hours, and aspirin and dilatiazem were given throughout the hospitalization unless adverse events or contraindications were present. Heparin was given intravenously for up to 7 days with an effort to maintain the activated partial thromboplastin time at 1.5 to 2 times greater than control values. Beta-blocking agents were withheld unless indicated for treatment of ventricular tachycardia, hypertension, or recurrent ischemia. Coronary artery bypass grafting was used only for very high-risk anatomy or other compelling clinical indications before follow-up angiography. After follow-up angiography, patients who were not considered to be candidates for angioplasty but who merited myocardial revascularization were treated with coronary artery bypass grafting.

Core anglographlc analysis. All coronary angiograms and left ventriculograms were analyzed at the Core Angiographic Laboratory at the University of Michigan. Observers were blinded to the specific treatment regimen. Global left ventricular ejection fraction was calculated by the area-length method, ${ }^{19}$ and regional left ventricular function was evluated by the centerline chord method of Sheehan et al. ${ }^{20}$

Criteria for use of IABP. No standard criteria for insertion of the IABP were used in any of the four protocols. The individual investigator at each center made the decision to insert the IABP based on the presence of demonstrated hemodynamic instability or coronary anatomy deemed to be extremely high risk. The reduction in reocclusion rates was not known until this study had been completed. Therefore this concept did not influence the selection of patients for IABP insertion.

Method of IABP insertion. All IABP placements were carried out by a cardiologist experienced with the percutaneous insertion technique. The IABP was inserted via the percutaneous route by means of the Seldinger technique. An $11 \mathrm{~F}$ arterial sheath was used for placement in the femoral artery, and the IABP catheter was introduced by means of a guide wire. Appropriate position in the descending aorta was verified by fluoroscopy in all instances. Adjustment in intravascular augmentation was verified by continuous measurement of arterial blood pressure. All patients were anticoagulated with intravenous heparin while the IABP was being used. Removal of the IABP was performed with back bleeding from the arterial site for 5 to 10 seconds to allow intravascular thrombi around the insertion site to disappear. The inguinal region was then compressed manually for a minimum of 30 minutes. After removal of the IABP, any loss of pulse in the peripheral arteries distal to the insertion site was evaluated by a vascular surgeon.

Collection and analysis of data. Data were entered onto case report forms at the clinical sites and the angiographic core laboratory, and the biostatistical core unit at Duke University provided quality control of the data. For descriptive purposes, results are expressed as percentages for discrete variables and mean ( \pm 1 standard deviation [SD]) for continuous variables.

\section{RESULTS}

Baseline characteristics. A descriptive summary of selected clinical and angiographic baseline characteristics is shown in Tables I and II. As expected, patients in whom the IABP was inserted had substantially more hemodynamic compromise, more multivessel and left anterior descending coronary artery disease, and more frequent failure to reperfuse at immediate angiography compared with patients in 
Table I. Baseline characteristics

\begin{tabular}{|c|c|c|}
\hline Characteristics & $\begin{array}{c}\text { Patients } \\
\text { with IABP } \\
(N=85)\end{array}$ & $\begin{array}{c}\text { Patients } \\
\text { without IABP } \\
(N=725)\end{array}$ \\
\hline Age (yr) & $58 \pm 10$ & $50 \pm 9$ \\
\hline Male sex $\left(c_{i}\right)$ & 81 & 80 \\
\hline \multicolumn{3}{|l|}{ Risk factors } \\
\hline Diabetes $\left(\begin{array}{c}0 \\
0\end{array}\right)$ & 20 & 14 \\
\hline Hypertension ( & 47 & 41 \\
\hline Weight (pounds) & $180 \pm 34$ & $181 \pm 33$ \\
\hline Peripheral vascular disease $(10)$ & 9 & 5 \\
\hline Cerebral vascular disease $\left(c_{0}^{*}\right)$ & 2 & 2 \\
\hline Previous myocardial infarction $(\%)$ & 25 & 12 \\
\hline \multicolumn{3}{|l|}{ Location of myocardial infarction } \\
\hline Anterior $(n)$ & 62 & 38 \\
\hline Inferior $(r i)$ & 38 & 62 \\
\hline $\begin{array}{l}\text { Admission systolic } \\
\text { blood pressure }(\mathrm{mm} \mathrm{Hg})\end{array}$ & $127 \pm 25$ & $133 \pm 25$ \\
\hline Admission heart rate & $85 \pm 21$ & $78 \pm 18$ \\
\hline Killip class > 1( & 30 & 19 \\
\hline
\end{tabular}

whom the IABP was not inserted. The greater prevalence of diabetes, hypertension, and older age also demonstrates the higher risk nature of the IABP population.

Timing and circumstances of insertion. The majority of IABP insertions occurred in the first 24 hours of the hospital course. Over $90 \%$ of insertions had been performed by the third day. The majority of the IABPs $(75 \%)$ were inserted before or during acute cardiac catheterization. Only four patients required insertion of the IABP later in the hospital course during or after cardiac surgery, whereas 16 IABPs (19\%) were inserted during the stay in the cardiac care unit in patients treated without surgery.

During the course of the four studies, the rate of IABP insertion ranged from a minimum of $10 \%$ in the TAMI I trial to a maximum of $13 \%$ in the TAMI II trial. Thus the rate of IABP insertion did not vary substantially over time. Similarly little variation existed from center to center in IABP use, with rates ranging from $7 \%$ to $13 \%$ of patients.

Clinical outcome. The in-hospital mortality rate of patients treated with IABP was substantially higher $(32 \%)$ than that in patients not requiring IABP support $(4 \%)$. The majority of deaths were due to progression of cardiogenic shock. No deaths resulted directly from complications of IABP insertion.

Table III shows multiple in-hospital clinical outcomes. As expected, because of the increased severity of illness, patients treated with the IABP had a higher rate of arrhythmic and hemodynamic complications compared with other patients. The length of hospitalization also was markedly longer in patients requiring use of the IABP.
Table II. Angiographic findings

\begin{tabular}{lcc}
\hline & $\begin{array}{c}\text { Patients } \\
\text { with IABP } \\
(N=85)\end{array}$ & $\begin{array}{c}\text { Patients } \\
\text { without IABP } \\
(N=725)\end{array}$ \\
\hline Coronary anatomy & & \\
$0-1$ vessel & $33 \%$ & $57 \%$ \\
2 vessels & $26 \%$ & $28 \%$ \\
3 vessels & $38 \%$ & $15 \%$ \\
Left main & $4 \%$ & $1 \%$ \\
TIMI grade & & \\
0 & $32 \%$ & $22 \%$ \\
1 & $12 \%$ & $6 \%$ \\
2 & $20 \%$ & $17 \%$ \\
3 & $36 \%$ & $55 \%$ \\
Infarct artery & & \\
Left anterior descending & $54 \%$ & $37 \%$ \\
Left circumflex & $12 \%$ & $13 \%$ \\
Right coronary & $32 \%$ & $49 \%$ \\
Left main & $2 \%$ & $0 \%$ \\
Graft & 0 & $1 \%$ \\
\hline
\end{tabular}

TIMI, Thrombolysis In Myocardial Infarction.

The most intriguing outcome was the absence of reocclusion for the duration of IABP insertion compared with the overall rate of $13 \%$ in the combined trials. Careful scrutiny of individual records showed that there were two patients who had reocclusion within hours after removal of the IABP. In another three patients the IABP was inserted after reocclusion had occurred, because of hemodynamic compromise, and a second reocclusion did not occur. Review of records of the patients who died showed no reinfarction during treatment with the IABP, which was supported by the findings of patent infarct-related arteries at autopsy in 12 patients. Five patients who later died had a reinfarction before insertion of the IABP.

The paired left ventricular function data are shown in Table IV. It is important that the number of paired observations is low in the group treated with IABP because of the high mortality rate, the severity of illness, and the frequent use of surgery in these patients. Nevertheless, IABP patients with paired data had a tendency toward an improvement in resting left ventricular function during the course of the hospitalization. These effects were most pronounced in the zone of myocardium distant from the site of infarction.

Complications. Bleeding complications in patients with IABPs were substantially greater than in those without IABPs (Table V). Even when patients treated with coronary artery bypass grafting were excluded, significant differences remained. Vascular complications were more common after IABP insertion compared with patients who only had the usual vascular access during their cardiac catheterization; loss of 
Table III. Clinical outcomes

\begin{tabular}{lcc}
\hline \multicolumn{1}{c}{$\begin{array}{c}\text { Clinical } \\
\text { outcome }\end{array}$} & $\begin{array}{c}\text { Patients } \\
\text { with IABP } \\
(N=85)\end{array}$ & $\begin{array}{c}\text { Patients } \\
\text { without IABP } \\
(N=725)\end{array}$ \\
\hline Death & $27(32 \%)$ & $28(4 \%)$ \\
Reocclusion (total) & $5(7 \%)^{*}$ & $88(13 \%)$ \\
Reocclusion with IABP & 0 & - \\
Pulmonary edema & $32(38 \%)$ & $74(10 \%)$ \\
Sustained hypotension & $48(56 \%)$ & $85(12 \%)$ \\
Ventricular tachycardia & $35(41 \%)$ & $129(18 \%)$ \\
$\quad$ or fibrillation & $36(42 \%)$ & $93(13 \%)$ \\
Cardiac arrest & $27 \pm 34$ days & $12 \pm 21$ days \\
Hospital stay &
\end{tabular}

*Three patients had reocclusion before the IABP was inserted; two patients had reocclusion after the IABP was removed.

Table IV. Left ventricular function results

\begin{tabular}{lcc}
\hline & $\begin{array}{c}\text { Patients } \\
\text { with IABP }\end{array}$ & $\begin{array}{c}\text { Patients } \\
\text { without IABP }\end{array}$ \\
\hline Global LV ejection fraction (o) & \\
Acute & $40 \pm 13$ & $52 \pm 11$ \\
Follow-up & $42 \pm 14$ & $53 \pm 11$ \\
$\quad$ Change & $+1.9 \pm 9.1$ & $+0.7 \pm 9.2$ \\
Regional infarct zone function* & \\
$\quad$ Acute & $-3.17 \pm 0.76$ & $2.50 \pm 1.10$ \\
Follow-up & $-2.63 \pm 1.04$ & $-2.12 \pm 1.25$ \\
Change & $+0.38 \pm 0.91$ & $+0.38 \pm 1.05$ \\
Regional noninfarct zone function* & \\
Acute & $-0.67 \pm 2.06$ & $+0.36 \pm 1.59$ \\
Follow-up & $-0.71 \pm 1.84$ & $+0.34 \pm 1.41$ \\
Change & $+0.11 \pm 1.05$ & $-0.09 \pm 1.20$ \\
\hline
\end{tabular}

*Values expressed as standard deviations per chord.

pulse occurred in $12 \%$ versus $2 \%$ and vascular repair in $6 \%$ versus $2 \%$, respectively. Of the 27 patients with IABPs who later died, autopsy information was available in $42 \%$. There was only one patient who had a vascular dissection noted at autopsy in this group. The patient died of progressive cardiac failure, and the death could not be attributed to complications of IABP insertion.

\section{DISCUSSION}

The findings in this observational study indicate that the IABP may be inserted safely in the setting of acute myocardial infarction treated with thrombolytic therapy, although the $11 \mathrm{~F}$ vascular access required in the femoral artery clearly increases the risk of bleeding and vascular trauma at the periaccess site. The most striking finding in this study was the absence of reinfarction or reocclusion of the infarctrelated artery in a large consecutive series of patients. In addition, patients who had IABP insertion showed improvement in global and noninfarct zone regional left ventricular function.

The greater severity of illness in the IABP group in every respect is not surprising, given the accepted indications for IABP use. In the absence of a control group we cannot accurately assess whether the observed $32 \%$ in-hospital mortality rate is lower or higher than would have been expected without IABP use. Similarly the potential impact on complication rates cannot be determined with confidence. Randomized trials will be necessary to determine the overall impact of the device on clinical outcomes.

The apparent impact of the IABP on reocclusion cannot be accounted for by other factors that were measured in our population. In previous studies of reocclusion, the only factor we could find to be associated with a lower risk of reocclusion was a higher peak fibrin(ogen) degradation product level. ${ }^{21,22}$ Others $^{23,24}$ have suggested that a lesser residual stenosis after thrombolysis was associated with a lower risk of reocclusion, but in this study the IABP group had a similar degree of residual stenosis compared with the non-IABP group. The possibility must be considered that a substantial number of reocclusion events occurred in the 27 patients who died. Careful review of their records, including autopsy reports in $42 \%$ of patients, showed no evidence of reinfarction. ${ }^{25}$

These findings are particularly pertinent to patients undergoing "rescue angioplasty" because of failure of thrombolytic therapy to achieve reperfusion. In our previous experience the reocclusion rate in this "rescue angioplasty" group has been high ${ }^{26}$ with an associated high mortality rate. ${ }^{26-28}$ The speculated mechanism by which the IABP could prevent reocclusion is the production of markedly enhanced diastolic cornary artery perfusion pressure. The resultant improvement in flow characteristics could retard recurrent thrombus formation and prevent closure of an intimal flap after acute angioplasty against the opposite vessel wall.

The serial left ventricular function data suggest that use of the IABP may enhance noninfarct zone function. These findings must be tempered, however, by consideration of the high death rate in the IABP group. Thus only "responders" may have survived, thereby providing an inaccurate impression of the overall effect of the intervention. Furthermore, previous studies have demonstrated that patients with the poorest baseline left ventricular function have the greatest improvement regardless of other therapy. ${ }^{29,}{ }^{30}$ Despite these reservations, serious con- 
Table V. Complications of IABP

\begin{tabular}{|c|c|c|c|c|}
\hline & \multicolumn{2}{|c|}{ Patients with IABP } & \multicolumn{2}{|c|}{ Patients without IABP } \\
\hline & Overall $(N=85)$ & Nonsurgical $(N=40)$ & Overall $(N=725)$ & Nonsurgical $(N=592)$ \\
\hline \multicolumn{5}{|l|}{ Systemic } \\
\hline Nadir hematocrit & $27 \pm 5$ & $29 \pm 5$ & $32 \pm 6$ & $33 \pm 5$ \\
\hline Delta hematocrit & $17 \pm 7$ & $16 \pm 7$ & $12 \pm 5$ & $10 \pm 5$ \\
\hline $\begin{array}{l}\text { Units transfused + Delta } \\
\text { hematocrit } \div 3\end{array}$ & $12 \pm 8$ & $8 \pm 7$ & $5 \pm 4$ & $4 \pm 3$ \\
\hline$>2$ units transfused & $59 \%$ & $24 \%$ & $17 \%$ & $7 \%$ \\
\hline \multicolumn{5}{|l|}{ Local } \\
\hline Femoral artery repair & $6 \%$ & $5 \%$ & $2 \sigma_{0}$ & 2 \\
\hline Loss of pulse & $12 \%$ & $20 \%$ & $2 \%$ & $2 \%$ \\
\hline
\end{tabular}

sideration should be given to the potential impact of improved coronary perfusion rates and afterload reduction on recovery of myocardial function.

Noninfarct zone function has recently been recognized as a critical factor in the assessment of prognosis. ${ }^{31-33}$ In experimental studies when an epicardial vessel is occluded, collateral flow to other areas of myocardium with critical stenoses may be impaired. ${ }^{34}$ In the TAMI experience absence of "compensatory hyperkinesis" in the noninfarct zone is a powerful predictor of in-hospital mortality. ${ }^{31}$ The IABP could reverse this phenomenon by three mechanisms: (1) reduced afterload, thereby reducing the myocardial oxygen demand; (2) directly by improving flow to the noninfarct zone across critical stenosis; and (3) indirectly by improving collateral flow through the subendocardium.

The bleeding complication rates as expected were significantly higher with the IABP than without it. Much of this difference was attributable to the greater need for cardiac surgery in patients with IABPs, but the higher complication rate persisted after these patients were eliminated from the analysis. It is important that none of the complications directly attributable to the $\mathrm{IABP}$ were considered to be life threatening. These complications are certainly directly related to the large size of the puncture hole produced by insertion of the IABP.

The vascular complication rate of $12 \%$ observed in this study compares favorably with previously described complication rates of approximately $20 \%{ }^{35-37}$ The relatively low incidence of vascular complications may be the result of the percutaneous insertion technique. ${ }^{38}$ Although some vascular complications of the IABP may only be discovered at autopsy, ${ }^{39}$ just one patient had an adverse event noted at autopsy in this study.

The limitations of this study must be recognized as the results are considered. First, although collection of data was rigorous and prospective, a specific protocol for criteria for use of the IABP was not in effect. Thus the circumstances of insertion were not uniform. Second, therapeutic effects cannot be directly assessed, since no adequate control group exists for comparison. Apparent effects of IABP use must be confirmed by other studies before these outcomes are extrapolated to other populations. Third, the results achieved in this study occurred in selected regional centers for the invasive care of patients with coronary disease. In the absence of the experience accumulated by these investigators, the complication and failure rates can be expected to be higher.

Before collection of these data, the rationale for using the IABP in conjunction with thrombolytic therapy predominately rested on the prolonged delay in recovery of myocardial function after reperfusion. Thus the IABP was used in these trials to provide hemodynamic support for patients with frank or impending cardiogenic shock. This study raises three additional issues for consideration in future trials and clinical practice. First, the absence of reocclusion in this population demands follow-up confirmation by independent studies. Second, improved global and noninfarct zone regional function in patients treated with the IABP may have resulted from enhanced flow in the presence of reperfusion or significant reduction in afterload. ${ }^{41,41}$ Finally, the combined demonstration that noninfarct zone regional function is a critical determinant of survival and that it may be enhanced by use of the IABP raises the possibility that strategies could be developed to detect noninfarct zone dysfunction early, with the use of the IABP, to prevent subsequent hemodynamic deterioration.

\section{SUMMARY}

To assess the risk and possible benefits of use of the percutaneous IABP in patients given thrombolytic 
therapy as treatment for acute myocardial infarction, we prospectively evaluated 810 consecutive patients entered into the TAMI trials. During hospitalization the 85 patients treated with the IABP had more cardiac risk factors, were slightly older ( 58 vs 56 years), and more often had anterior infarction $(62 \%$ vs $38 \%$ ). At acute cardiac catheterization, patients treated with the IABP also had more multivessel coronary disease ( $67 \%$ vs $43 \%$ ), more frequent TIMI grade 0 or 1 flow ( $44 \%$ vs $28 \%$ ), lower global ejection fraction $(40 \%$ vs $52 \%)$, and worse regional infarct $(-3.2$ vs $-2.5 \mathrm{SD} / \mathrm{chord})$ and noninfarct $(-0.67$ vs $+0.36 \mathrm{SD} /$ chord) zone function. Although mortality rates $(32 \%$ vs $4 \%)$ and in-hospital complications were greater in patients treated with the IABP, a greater improvement in global (delta ejection fraction: $+1.9 \%$ vs $+0.7 \%$ ) and noninfarct zone (delta SD/chord: +0.11 vs -0.09 ) left ventricular function was observed in patients treated with the IABP at 1-week follow-up angiography. In addition, no reinfarction or reocclusion of the infarct-related artery occurred while patients were being treated with the IABP.

These results suggest that the IABP may have a specific role after thrombolytic therapy in treating patients at high risk for reocclusion or at high risk for hemodynamic deterioration because of large infarction or critical stenoses in coronary vessels supplying the noninfarct zone.

The authors wish to acknowledge the assistance of Cynthia Day and Wendy Pulliam in the preparation of this manuscript.

\section{REFERENCES}

1. Levine FH, Gold HK, Leinbach RC, Daggett WM, Austen WG, Buckley MJ. Management of acute myocardial ischemia with intraaortic balloon pumping and coronary bypass surgery. Circulation 1978;58(suppl I):I-69-I-72.

2. Williams DO, Korr KS, Gewirtz H, Most AS. The effect of intraaortic balloon counterpulsation on regional myocardial blood flow and oxygen consumption in the presence of coronary artery stenosis in patients with unstable angina. Circulation 1982;66:593-7.

3. Kantrowitz A, Krakauer JS, Rosenbaum A, Butner AN, Freed PS, Jaron D. Phase-shift balloon pumping in medically refractory cardiogenic shock. Arch Surg 1969;99:739-43.

4. Flaherty JT, Becker LC, Weiss JL, Brinker JA, Bulkley BH, Gerstenblith G, Kallman CH, Weisfeldt ML. Results of a randomized prospective trial of intraaortic balloon counterpulsation and intravenous nitroglycerin in patients with acute myocardial infarction. J Am Coll Cardiol 1985;6:434-46.

5. O'Rourke MF, Norris RM, Campbell TJ, Chang VP, Sammel NL. Randomized controlled trial of intra-aortic balloon counterpulsation in early myocardial infarction with acute heart failure. Am J Cardiol 1981;47:815-20.

6. Braunwald E. Myocardial reperfusion, limitation of infarct size, reduction of left ventricular dysfunction, and improved survival. Circulation 1989;79:441-4.

7. Califf RM, Topol EJ, Gersh BJ. From myocardial salvage to patient salvage in acute myocardial infarction: the role of reperfusion therapy. J Am Coll Cardiol 1989;14:1382-8.
8. Topol EJ. Coronary angioplasty for acute myocardial infarction. Ann Intern Med 1988;109:970-80.

9. Topol EJ, Califf RM. Tissue plasminogen activator: why the backlash? J Am Coll Cardiol 1989;13:1477-80.

10. Braunwald E, Kloner RA. The stunned myocardium: prolonged postischemic ventricular dysfunction. Circulation 1982; 66:1146-9

11. Grines CL, Topol EJ, Bates ER, Juni JE, Walton JA, O'Neill WW. Infarct vessel status after intravenous tissue plasminogen activator and acute coronary angioplasty: prediction of clinical outcome. AM HEART J 1988;115:1-7.

12. Fuchs RM, Brin KP, Brinker JA, Guzman PA, Heuser RR, Yin FCP. Augmentation of regional coronary blood flow by intraaortic balloon counterpulsation in patients with unstable angina. Circulation 1983;68:117-23.

13. Califf RM, Topol EJ, George BS, Boswick JM, Abbottsmith C, Sigmon KN, Candela R, Masek R, Kereiakes D, O'Neill WW, Stack RS, Stump D, and the Thrombolysis and Angioplasty in Myocardial Infarction Study Group. Hemorrhagic complications associated with the use of intravenous tissue plasminogen activator in treatment of acute myocardial infarction. Am J Med 1988;85:353-9.

14. Kantrowitz A, Wasfie T, Freed PS, Rubenfire M, Wajszczuk W, Schorkk MA. Intraaortic balloon pumping 1967 through 1982: analysis of complication in 733 patients. Am J Cardiol 1986;86:976-83.

15. Topol EJ, Califf RM, George BS, Kereiakes DJ, Abbottsmith CW, Candela RJ, Lee KL, Pitt B, Stack RS, O'Neill WW, and the Thrombolysis and Angioplasty in Myocardial Infarction Study Group. A randomized trial of immediate versus delayed elective angioplasty after intravenous tissue plasminogen activator in acute myocardial infarction. N Engl J Med 1987; $317: 581-6$.

16. Topol EJ, Califf RM, George BS, Kereiakes DJ, Rothbaum D Candela RJ, Abbottsmith CW, Pinkerton CA, Stump DC Dollen D, Lee KL, Pitt B, Kline EM, Buswick JM, O'Neill WW, Stack RS, and the TAMI Study Group. Coronary arterial thrombolysis with combined infusion of recombinant tissue-type plasminogen activator and urokinase in patients with acute myocardial infarction. Circulation 1988;77:1100-7.

17. Topol EJ, George BS, Kereiakes DJ, Stump DC, Cancela RJ, Abbottsmith CW, Aronson L, Pickel A, Boswick JM, Lee KL, Ellis SG, Califf RM, and the TAMI Study Group. A randomized controlled trial of intravenous tissue plasminogen activator and early intravenous heparin in acute myocardial infarction. Circulation 1989;79:281-6.

18. Wall TC, Phillips III HR, Stack RS, Mantell S, Aronson L, Boswick J, Sigmon K, DiMeo M, Chaplin D, Whitcomb D, Pasi D, Zawodniak M, Hajisheik M, Hegde S, Barker W, Tenney R, Califf RM. Results of high dose intravenous urokinase for acute myocardial infarction. Am J Cardiol 1990;65:124-31.

19. Dodge HT, Sandler H, Ballew DW, Lord Jr JD. The use of biplane angiocardiography for the measurement of left ventricular volume in man. AM HEART J 1960;60:762-76.

20. Sheehan FH, Bolson EL, Dodge H'T, Mathey DG, Schofer J, Woo HW. Advantages and applications of the centerline method for characterizing regional ventricular function. Circulation 1986;74:293-305.

21. Ellis SG, Topol EJ, George BS, Kereiakes DJ, Debowey D, Sigmon KN, Pickel A, Lee KL, Califf RM. Recurrent ischemia without warning: analysis of risk factors for in-hospital ischemic events following successful thrombolysis with intravenous tissue plasminogen activator. Circulation 1989;80: 1159-65.

22. Stump DC, Califf RM, Topol EJ, Sigmon K, Thornton D, Masek R, Anderson L, Collen D, and the TAMI Study Group. Pharmacodynamics of thrombolysis with recombinant tissuetype plasminogen activator: correlation with characeristics of and clinical outcomes in patients with acute myocardial infarction. Circulation 1989;80:1222-30.

23. Harrison DG, Ferguson DW, Collins SM, Skorton DJ, Ericksen EE, Kioschos JM, Marcus ML, White CW. Rethrombosis 
after reperfusion with streptokinase: importance of geometry of residual lesions. Circuilation 1984;69:991-9.

24. White CW. Recurrent ischemic events after successful thrombolysis in acute myocardial infarction: the Achilles' heel of thrombolytic therapy. Circulation 1989;80:1482-5.

25. Ohman EM, Sigmon K, Wall TC, Lee KL, Candela RJ, for the TAMI Study Group. Why do people die after thrombolytic therapy? Circulation 1989;80:II-349.

26. Califf RM, Topol EJ, George BS, Boswick JM, Lee KL, Stump D, Dillon J, Abbottsmith C, Candela RJ, Kereiakes DJ, O'Neill WW, Stack RS, and the TAMI Study Group. Characeristics and outcome of patients in whom reperfusion with intravenous tissue-type plasminogen activator fails: results of the thrombolysis and angioplasty in myocardial infarction (TAMI) I trial. Circulation 1988;77:1090-9.

27. Gacioch GM, Topol EJ. Sudden, paradoxical clinical deterioration during angioplasty of the occluded right coronary artery in acute myocardial infarction. J Am Coll Cardiol 1989; $14: 1202-9$

28. O'Connor CM, Mark DB, Hinohara T, Stack RS, Rendall D, Hlatky MA, Pryor DB, Phillips III HR, Califf RM. Rescue coronary angioplasty after failure of intravenous streptokinase in acute myocardial infarction: in-hospital and long-term outcomes. J Invasive Cardiol 1989:1:85-95.

29. Marzoll U, Kleiman N, Mulcahey S, Minor S, Verani M, Raizner A. Importance of baseline ejection fraction in response to reperfusion therapy in acute MI. Circulation 1988;78(suppl II):II-213.

30. Califf RM, Parsons WJ, Tcheng JE, Hinohara T, Boswick JM, Honan MB, Wall TC. Bascline function, not time to treat ment, is most closely associated with LV function improvement during the first week after thrombolytic therapy. Circulation 1988;78(suppl II):II-213.

31. Grines CL. Topol EJ, Califf RM, Stack RS, George BS, Kereiakes D, Boswick JM, Kline E, O'Neill WW, and the TAMI Study Group. Prognostic implications and predictors of enhanced regional wall motion of noninfarct zone after thrombolysis and angioplasty therapy of acute myocardial infarction. Circulation 1989;80:245-53.

32. Stack RS, Phillips HR, Grierson DS, Behar VS, Kong Y, Peter
RH, Swain JL, Greenfield JC. Functional improvement of jeopardized myocardium following intracoronary streptokinase infusion in acute myocardial infarction. J Clin Invest 1983;72:84-95.

33. Schmidt WG, Sheehan FH, von Essen R, Uebis R, Effert S. Evolution of left ventricular function after intracoronary thrombolysis for acute myocardial infarction. Am J Cardiol 1989;63:497-502.

34. Wilson JL, Ramanathan KB, Ingram LA, Mirvis DM. Effects of residual stenosis on infarct size and regional transmural myocardial blood flow after reperfusion. AM HEART $J$ 1988;116:1523-9.

35. Iverson LIG, Herfindahl G, Ecker RR, Young JN, Ennix CL, Lee J, Dunning C, Whisenant A, May IA. Vascular complications of intraaortic balloon counterpulsation. Am $J$ Surg 1987;154:99-103.

36. Gottlieb SO, Brinker JA, Borkon M, Kallman CH, Potter SA, Gott VL, Baughman KL. Identification of patients at high risk for complications of intraaortic balloon counterpulsation: a multivariate risk factor analysis. Am J Cardiol 1984;53: 1135-9.

37. Goldberger M, Tabak SW, Shah PK. Clinical experience with intra-aortic balloon counterpulsation in 112 consecutive patients. AM HEART J 1986;111:497-502.

38. Vignola PA, Swaye PS, Gosselin AJ. Guidelines for effective and safe percutaneous intraaortic balloon pump insertion and removal. Am .J Cardiol 1981;48:660-4.

39. Isner JM, Cohen SR, Virmani R, Lawrinson W, Roberts WC. Complications of the intraaortic balloon counterpulsation device: clinical and morphologic observations in 45 necropsy patients. Am J Cardiol 1980;45:260-8.

40. Pfeffer MA, Lamas GA, Vaughan DE, Parisi AF, Braunwald E. Effect of captopril on progressive ventricular dilatation after anterior myocardial infarction. N Engl J Med 1988;319: 80-6.

41. Nabel EG, Topol EJ, Galeana A, Bates ER, Werns SW, Walton JA, Pitt B. A randomized, double-blind, placebo controlled, pilot trial of combined early intravenous captopril and tPA therapy in acute myocardial infarction. Circulation 1989;80(suppl II):II-112. 